\title{
MEASUREMENT OF SHARIAH STOCK PERFORMANCE USING RISK ADJUSTED PERFORMANCE
}

\author{
Zuhairan Y Yunan \& Mia Rahmasari ${ }^{1}$
}

\begin{abstract}
Abstrak. Measurement of Shariah Stock Performance Using Risk Adjusted Performance. The aim of this research is to analyze the shariah stock performance using risk adjusted performance method. There are three parameters to measure the stock performance i.e. Sharpe, Treynor, and Jensen. This performance's measurements calculate the return and risk factor from shariah stocks. The data that used on this research is using the data of stocks at Jakarta Islamic Index. Sampling method that used on this paper is purposive sampling. This research is using ten companies as a sample. The result shows that from three parameters, the stock that have a best performance are AALI, ANTM, ASII, CPIN, INDF, KLBF, LSIP, and UNTR.
\end{abstract}

Keywords: Risk Adjusted Performance, Stock Performance, Shariah Stock

\begin{abstract}
Abstrak. Pengukuran Kinerja Saham Syariah Menggunakan Risk Adjusted Performance.. Tulisan ini bertujuan memberikan gambaran mengenai kinerja saham-saham syariah di Indonesia dengan menggunakan metode Risk Adjusted Performance. Terdapat tiga parameter yang digunakan untuk mengukur kinerja saham yaitu: Sharpe, Treynor, dan Jensen. Metode pengukuran kinerja ini memperhitungkan faktor tingkat pengembalian (return) dan tingkat resiko dari saham-saham syariah. Data yang digunakan yaitu saham-saham yang terdaftar di Jakarta Islamic Index periode Januari 2008 - Desember 2012. Penarikan sampel dilakukan dengan metode purposive sampling dari populasi sehingga diperoleh sampel sebanyak 10 perusahaan. Berdasarkan ketiga parameter tersebut diperoleh saham dengan peringkat kinerja terbaik yaitu AALI, ANTM, ASII, CPIN, INDF, KLBF, LSIP, dan UNTR.
\end{abstract}

Kata Kunci: Risk Adjusted Performance, Kinerja Saham, Saham Syariah

First draft: October, 4th 2014, Revision: December, 5th 2014, Accepted: December, $20^{\text {th }}$

1 Syarif Hidayatullah State Islamic University Syarif Hidayatullah Jakarta, Jl. Ir. H. Juanda No. 95, Ciputat, South Tangerang, Banten.

University of Prof Dr. Hamka (Uhamka), Jl. Limau, Kebayoran Baru, South Jakarta

Email: zuhairan@uinjkt.ac.id, miarahmasari2@gmail.com 


\section{Introduction}

Islam is a way of life that is balanced and integrated, designed to deliver human happiness through enforcement of harmony between the needs of human moral and material, and the actualization of socio-economic justice and brotherhood in society. The call for justice-oriented welfare and the balance is repeated five times each day. The Muslims have embarked welcomed this call and there is a revival in the Islamic world. This revival is also reflected in the intellectual field (Chapra, 1996). The Islamic economic system teaches us to balance the life of the world and the hereafter. Islam also teaches that we balance between personal interests, other people, society, and the universe. Islam forbids speculation (gharar), uncertainty (juhala), riba (interest), and all forms of cheating, fraud and various actions that harm others. As an alternative to economic muamalah, Islam teaches the concept of sharing (Nafik, 2009).

One model of economic development in the era of globalization is the development of capital markets in the country. Capital markets as an alternative funding for the development of the business world has a strategic role in the implementation of national development and also serves as one of the investment advice to investors who have excess funds. The investor is investing excess funds at their disposal, parties who have excess funds in anticipation of receiving compensation from the fund allocation.

One of the Islamic financial instruments that are growing is the Islamic financial market. The development of Islamic financial market is very rapidly in the world, both money markets and capital markets, especially in countries where the majority Muslim population. It is characterized by the establishment of the Islamic Financial Market in Kuala Lumpur which was pioneered by Islamic countries (Hamid, 2009). In the capital market-based Indonesian Islam is Jakarta Islamic Index, which was launched in cooperation with PT. Jakarta Stock Exchange (JSX) in cooperation with PT. Danareksa Investment Management (DIM) which took place in 2000. The stock exchange based on Islamic values also exist in countries that apply the ideology of capitalism in the economic development of the world, namely on Wall Street, the Dow Jones. Wall Street, the Dow Jones in 1999 precisely in February has launched Dow Jones Islamic Market Index (DJIMI) which is welcomed by many parties that were hit by the crisis of confidence in the capital markets of conventional (Mohammed, 2007).

The existence of capital markets helped build the national economy. Capital market became one of the most important factors, have proven many industries and companies that use this capital market institutions as a medium to absorb investment 
and media to strengthen its financial position. Moreover, not many people are aware that the Sharia-compliant investment not only in the banking and insurance sector but also present in the Islamic capital market. The development of Islamic stocks will continue to rise in line with market demand. This suggests that the growth of the Islamic capital market that is prospective in the next year based on some of the advantages that can be obtained by issuers and investors. Issuers are included in the list of Islamic securities have a much broader market because they can sell the securities, both to Islamic institutions and non-islamic institution.

There are two factors that can affect stock investment. First, through the fundamental factors such as performance and the company's internal conditions that tends to be controlled. Second, technical factors that reflected the conditions of macro-economic indicators such as inflation, interest rates of SBI, the money supply, exchange rate against the USD, the Gross Domestic Product (GDP), balance of payments such as exports and imports, foreign exchange reserves, stock index in the world market, security and political conditions, and etc.

Both of these factors can be used as a basis for investors to predict returns, risk or uncertainty, the amount, timing, and other factors associated with an investment in the capital market activities. Investment in the capital market is basically aimed at obtaining returns, but investors should consider the risks that must be endured. To overcome and minimize risk, investors need to diversify by creating a portfolio. In the formation of a portfolio, an investor needs to evaluate the performance of the portfolio. In investing, the investor would consider the best possible company to which capital will be invested. The selected firm course healthy company and produce a good performance. Market participants, especially investors should conduct performance measurements to decide on stock shares which it will invest. This indicates that in addition to the aspect of sharia, also should pay attention to the aspect of prudence.

This paper evaluates the performance of stocks in Jakarta Islamic Index began the period January 2008 to December 2012, namely, stock-listed since the launch of the index in 2000. Selection of the study period in 2008, because in that year the global financial crisis in the world, then in later years that the year 20092012 as the period of recovery from the global crisis, as well as the development of the sharia stock performance in Indonesia until now. The variables used are stock performance. Risk is calculated with the beta, the rate of return calculated by the expected return. To calculate the performance of the stock used method of Risk Adjustment Performance. 


\section{Literature Review}

In concept, the investment is allocated activities or resources investment at this time, in the hope of benefit in the future (Noor, 2009). Therefore, understanding the investment can be formulated as a sacrifice of current consumption opportunities, to get a benefit in the future. With the postponement of consumption currently used for the investment is expected to benefit in the future. In Islam, investment activities can be categorized as economic activities including muamalah activity i.e. an activity that regulates the relationship between humans (Sutedi, 2011).

Capital market is a means to reconcile a party that has excess funds to the cash-strapped, which traded funds are a long-term funds (Manan, 2009). Trading in the stock market occur, both in the primary market and the secondary market. The primary market is the first sale of securities to the public (Fakhruddin, 2008). Through the primary market, or better known as the IPO (Initial Public Offering) the company issuing the securities actually receive the funds. The next trade occurs in the secondary market. The useful of secondary market for securities owners to sell securities, either for reasons to obtain liquidity or to gain or increase in the price of these securities (Darmawi, 2006). Islamic capital market is a market where the activities carried out in accordance with Islamic principles. Islamic capital market presents affirmation of religious law in capital market transactions in which the free market of activities that are prohibited and of elements such as usury, gambling, and gharar (Huda, 2009).

There are several requirements that must be met to be an efficient market, all the terms of the efficient market is in accordance with the Quran and the Hadith is as follows (Hamid, 2009). First, the stock price should be free to go down or up. Second, there is no monopoly in the market. Third, there should be a requirement that requires companies disclose information about themselves. Fourth, Cost to get information is to a minimum, and that information must be received by the investor at the same time. Fifth, the information is randomized and independently. Sixth, the investor can take a quick action for the new information.

As already explained, the efficient market must meet these requirements, otherwise it may be said that the market is not in accordance with the Islamic concept. There are fundamental differences between the conventional capital markets with the Islamic capital market. Islamic capital market does not know the sort of short selling activity -Buy trading or selling in a very short time to get the advantage of the difference between the selling and buying. Sharia shareholder is a shareholder for a relatively long period. Such a pattern of share ownership has a positive impact. The company will surely get shareholders that are more attentive and have a sense of belonging; this would be an effective control. The Company and 
shareholders are partners who respect each other and remind that the two sides will meet communication in order to achieve the good of both parties. Characteristics of Islamic stock ownership only priority achievement gains or losses will be shared will be shared (profit and loss sharing), will not create sharp fluctuations in trading activities and speculative (Manan, 2009).

Stocks that entered into sharia index is the issuer whose business is not contrary to the shariah, such as gambling businesses, businesses conventional financial institutions, businesses that produce, distribute, and trade food and drink that are unlawful and destructive nature of moral and disadvantages. In stock selection process that goes Jakarta Islamic Index, Indonesia Stock Exchange do stages election also consider aspects of liquidity and financial condition of the issuer, ie selecting a collection shares with the main type of business already recorded more than 3 months, pick stocks based on the annual financial statements or the middle of the year ended which has a maximum ratio of liabilities to assets by $90 \%$, choose 60 shares of stock composition above is based on an average order of the largest market capitalization over the past year, and chose the 30 stocks with the order based on the average level of liquidity regular trading value during one last year (Sutedi, 2011).

Jakarta Islamic Index is an index developed by the JSE in cooperation with Danareksa Investment Management to respond to the needs of information relating to Islamic investment. Jakarta Islamic Index filtered the listing of shares. The reference in the filtration is Islamic fatwa issued by the National Islamic Council (DSN). With this fatwa Jakarta Stock Exchange listed companies sort out its business units in accordance with sharia (Hamid, 2009).

The fundamental difference between the conventional index with the index of Islam is conventional indices include all stocks listed on the exchange by ignoring aspects of halal haram, which is important stocks listed issuer (listing) is in conformity with the applicable rules (legal) (Sutedi, 2011). As a result, it is not a problem if there are issuers who sell their shares on the stock moves in the business sector are contrary to Islamic principles.

\section{Methods}

This paper uses a quantitative approach with secondary data analysis methods. The analysis used in assessing the performance of stocks of sharia is the approach of Risk Adjusted Performance. The object of this research is to study the stocks listed in the Jakarta Islamic Index in the period 2008 to 2012. In this study the object of study is the Islamic stock performance. The Islamic stocks as measured its performance is consistently listed shares in Jakarta Islamic Index. The selection of stocks consistently listed in the Jakarta Islamic Index once every 6 months because 
the stocks listed in the Jakarta Islamic Index is evaluated whether it was feasible with the assessment and specific criteria.

Sampling technique in this study using purposive sampling, the sample selection based on certain criteria. The criteria that must be met, namely in this study that became the object of study is the Islamic stock performance. The Islamic stocks as measured its performance is consistently listed shares in Jakarta Islamic Index. The selection of stocks consistently listed in the Jakarta Islamic Index once every 6 months because the stocks listed in the Jakarta Islamic Index is evaluated whether it was feasible with the assessment and specific criteria. Stocks that are consistently listed in the Jakarta Islamic Index during the period 2008-2012 can be seen in Table 1. The data used in this paper is secondary data which data are: the shariah stock price, market price of Jakarta Islamic Index, Bank Indonesia Certificates Sharia as the risk free rate. As well, several other publications relating to the shares listed on the Jakarta Islamic Index as an object of study.

Table 1. Stocks that consistent listed in Jakarta Islamic Index, year 2008-2012

\begin{tabular}{ccl}
\hline No. & Code & \multicolumn{1}{c}{ Name } \\
\hline 1. & AALI & Astra Agro Lestari Tbk \\
2. & ANTM & Aneka Tambang (Persero) Tbk \\
3. & ASII & Astra Internasional Tbk \\
4. & CPIN & Charoen Pokphand Indonesia Tbk \\
5. & INDF & Indofood Sukses Makmur Tbk \\
6. & KLBF & Kalbe Farma Tbk \\
7. & LSIP & PP London Sumatera Tbk \\
8. & SMGR & Semen Gresik (Persero) Tbk \\
9. & TLKM & Telekomunikasi Indonesia Tbk \\
10. & UNTR & United Tractors Tbk \\
\hline
\end{tabular}

Source: Indonesian Stock Exchange, 2013

In this paper, the method used to measure the performance of the stock is to use the Risk Adjustment Performance measurement method. The process is as follows: first, develop and establish a sharia stocks included in the Jakarta Islamic Index during the period January 2008 - December 2012. Second, Determination of the study sample with the criteria is consistent stock included in the calculation of the Jakarta Islamic Index during the study period. Third, collect the individual stock's price data during the study period. Fourth, collect the data of Bank Indonesia's certificate as a monthly risk free asset. Fifth, calculate the monthly stock's return. Sixth, calculate the deviation standard and stock's beta. Seventh, measure the sharia stock's performance using risk adjusted performance. 
Once these stages carried out, then compare the performance of the shares of sharia with Risk Adjusted Performance of the method which has the best performance to be able to invest. The calculation is performed by calculating the standard deviation, beta stocks using stock price data and SBIS. Stock performance analysis is using Risk Adjusted Performance with three parameters, namely the method of Sharpe, Treynor, and Jensen.

Treynor's models is the size of the investment performance using the excess return of the beta, the risk can't be eliminated through diversification. This model firstly proposed by Jack Treynor so called Treynor Index. This measurement assumes that the portfolio is well diversified, so that the risk in the portfolio is only systematic risk (Zubir, (2011). In evaluating the performance of mutual funds (stocks) Treynor using the average return of the past as the expected return and use the beta as a measure of risk. Beta indicates the size of the change in the return of a stock to changes in market return, Rm (Samson, 2006). The higher the Treynor's ratio, the performance of the portfolio will be better. As a measure of investment risk is used beta because in general fluctuations in stock prices affected by market fluctuations. Average return is still regarded as the best measure for the return guidelines predictions, assuming all markets are efficient. Comparison between return and risk show investors that the higher the risk the higher the expected return. Treynor's model can be write as follow (Samsul, 2006):

$$
\mathrm{R} / \mathrm{V}_{\mathrm{t}}-\left(\mathrm{R}_{\mathrm{p}}-\mathrm{R}_{\mathrm{f}}\right) / \beta_{\mathrm{p}}
$$

Where:

$\begin{array}{ll}\mathrm{R}_{\mathrm{V}} & =\text { reward to volatility model Treynor; } \\ \mathrm{R}_{\mathrm{p}} & =\text { average return portofolio; } \\ \mathrm{R}_{\mathrm{f}} & =\text { risk free rate; } \\ \beta \beta_{\mathrm{p}} & =\text { portfolio beta }\end{array}$

The second measurement model is a model of Sharpe. Basic measurement methods Sharpe is the risk premium, i.e. the difference between the average performances produced by the average stock with a risk-free investment performance. The indication is the higher the Sharpe ratio, the better the performance of a stock (Nature, 2010). The performance of mutual funds in the future can be predicted by using two measures, namely the expected rate of return (E) and predicted variability of risk is expressed as a deviation standard return, $\sigma \sigma_{\mathrm{p}}$ (Samson, 2006).

Expected rate return is the average annual return. Predicted variability of risk is the standard deviation of annual return. The standard deviation shows the change value of return on average return. Excess return is the difference between the average rates of return minus the risk free rate. Sharpe's model can be written as follows 
(Samsul, 2006):

$$
\mathrm{R} / \mathrm{V}_{\mathrm{s}}=\left(\mathrm{R}_{\mathrm{p}}-\mathrm{R}_{\mathrm{f}}\right) / \sigma \sigma_{\mathrm{p}}
$$

Where:

$$
\begin{array}{ll}
\mathrm{R}_{\mathrm{V}} \mathrm{V}_{\mathrm{s}} & =\text { reward to variability ratio model Sharpe } \\
\mathrm{R}_{\mathrm{p}} & =\text { average portofolio's return } \\
\mathrm{R}_{\mathrm{f}} & =\text { risk free rate } \\
\sigma \sigma_{\mathrm{p}} & =\text { standard deviation of portofolio's return }
\end{array}
$$

Performance measurement model of Treynor and Sharpe models are complementary to each other because of different information. The non-diversified portfolio is going to get high rankings for Treynor, but rank lower for measurement Sharpe.

In the Jensen models, it is assumed that the investor will invest if it can generate a return that exceeds the expected return or the minimum rate of return (Samson, 2006). Jensen uses the beta factor in measuring the performance of a portfolio investment. Investment portfolio performance measurement using this model Jensen measure the real return to the expected return, assuming that it has a well-diversified portfolio (Hadi, 2013). The Jensen's model can be written as follows (Samsul, 2006):

$$
\mathrm{E}\left(\mathrm{R}_{\mathrm{j}}\right)=\mathrm{R}_{\mathrm{f}}+\beta \beta_{\mathrm{j}}\left[\mathrm{E}\left(\mathrm{R}_{\mathrm{m}}\right)-\mathrm{R}_{\mathrm{f}}\right]
$$

Where:

$$
\begin{array}{ll}
\mathrm{E}\left(\mathrm{R}_{\mathrm{j}}\right) & =\text { expected return of stock } \mathrm{j} \\
\mathrm{R}_{\mathrm{f}} & =\text { risk free, } \text { interest rate } \\
\beta \beta_{\mathrm{j}} & =\text { beta of stock } \mathrm{j} \\
\mathrm{E}\left(\mathrm{R}_{\mathrm{m}}\right) & =\text { expected market return }
\end{array}
$$

\section{Discussion}

One of the indicators that can be used and easy to predict the performance of Islamic stocks is by looking at the development of the stock return itself. Here is a table of the average return of sharia stocks from 2008 through 2012

Table 2. Average Return of Shariah Stock (\%)

\begin{tabular}{lccccc}
\hline Emiten & $\mathbf{2 0 0 8}$ & $\mathbf{2 0 0 9}$ & $\mathbf{2 0 1 0}$ & $\mathbf{2 0 1 1}$ & $\mathbf{2 0 1 2}$ \\
\hline AALI & $-5,25$ & 7,48 & 1,47 & $-1,28$ & $-0,49$ \\
ANTM & $-10,07$ & 6,83 & 1,32 & $-2,97$ & $-1,06$ \\
ASII & $-12,26$ & 11,13 & 4,22 & 2,78 & $-7,50$ \\
CPIN & $-5,10$ & 16,42 & 7,64 & 2,55 & 5,11
\end{tabular}




\begin{tabular}{lccccc} 
INDF & $-7,41$ & 12,64 & 3,03 & $-0,13$ & 2,10 \\
KLBF & $-8,09$ & 11,55 & 8,56 & 0,62 & $-2,90$ \\
LSIP & $-7,19$ & 9,83 & 1,72 & $-6,91$ & 0,93 \\
SMGR & $-1,77$ & 5,43 & 2,08 & 2,15 & 3,00 \\
TLKM & $-2,41$ & 4,45 & $-1,77$ & $-0,94$ & 2,37 \\
UNTR & $-3,12$ & 11,70 & 3,79 & 1,26 & $-0,01$ \\
\hline
\end{tabular}

Source: Indonesian Stock Exchange

Based on Table 2, the overall 2009 was a year with the best sharia stock returns where the return of the tenth Islamic stocks is positive. Fluctuations in stock returns occur each year, because affected by the performance of the company itself whether it is in a good or bad performance. Fluctuations in stock returns are influenced by internal factors and external factors such as economic conditions. Based on the data, all the stock has a negative return in 2008, but in 2009 the company could get up and improve its performance.

Islamic stocks return that have increased in every year are AALI, ANTM, CPIN, INDF, KLBF, LSIP, TLKM SMGR and this can be considered an investor to invest in the stock. There are some stocks that show a negative return almost every year, it shows that the company is not in a good performance and easily affected by negative sentiments. Although the stocks have the good performance this year, it is likely affected by negative sentiment in the coming years, therefore, as an investor must be responsive to address the outstanding issues so that no one take investment decisions.

The Sharpe's model measurement is emphasis on total risk or standard deviation. The standard deviation indicates the size of the change in the return of a share of the average return of the stock. To predict the future performance of the period used the data from the previous period. Return on average the previous period is considered as a return prediction coming period and the standard deviation of the return of the previous period is considered as a risk prediction coming period. To analyze the performance of the model of Sharpe, the required data is average stock returns, standard deviations, and the risk free rate. The results of the calculation of the stock performance of the group shares the Jakarta Islamic Index Sharpe method for each period can be seen in Table 3 .

Table 3. Stock's Performance Using Sharpe's Model

\begin{tabular}{cccccc}
\hline Emiten & $\mathbf{2 0 0 8}$ & $\mathbf{2 0 0 9}$ & $\mathbf{2 0 1 0}$ & $\mathbf{2 0 1 1}$ & $\mathbf{2 0 1 2}$ \\
\hline AALI & $-24,371$ & 95,404 & 11,477 & $-24,074$ & $-10,231$ \\
ANTM & $-76,310$ & 43,266 & 8,272 & $-35,671$ & $-10,805$
\end{tabular}




\begin{tabular}{cccccc} 
ASII & $-80,086$ & 82,031 & 39,763 & 33,038 & $-29,313$ \\
CPIN & $-33,521$ & 71,545 & 21,011 & 11,572 & 40,305 \\
INDF & $-51,625$ & 82,543 & 27,716 & $-7,818$ & 41,080 \\
KLBF & $-69,088$ & 60,938 & 66,036 & 1,072 & $-12,964$ \\
LSIP & $-33,155$ & 66,330 & 9,268 & 30,297 & 4,567 \\
SMGR & $-21,493$ & 52,689 & 22,963 & 14,650 & 34,595 \\
TLKM & $-28,596$ & 42,070 & $-36,918$ & $-46,688$ & 25,187 \\
UNTR & $-16,331$ & 87,303 & 54,975 & 7,643 & $-2,628$ \\
\hline
\end{tabular}

Source: Indonesia Stock Exchange

Table 3 shows that the Sharpe index of the period 2008 to 2012 was in the range -80086 to 95404 . If the value of the Sharpe's performance index is positive and always increasing, it shows the better stock performance. Every year Sharpe index is always fluctuating. There are some sharia stocks from 2008 until 2012 that always show increased Sharpe performance index, namely: AALI, ANTM, CPIN, INDF, SMGR, and TLKM. The period 2008 to 2012, Sharpe index shows that almost evenly in each year there are still stocks is negative. This indicates that the stock portfolios of Jakarta Islamic Index, yet all of them have a positive Sharpe index. Table 3 shows the Islamic stocks from 2008 to 2012 which showed a decrease in the performance index Sharpe namely: ASII, KLBF, LSIP, and UNTR.

In evaluating the performance of the stock with a Treynor's model is by using the average return the previous period as the expected return and beta as a measure of risk. Beta indicates the size of the change in the return of a stock to changing market return. As a investment risk benchmark is used beta, because in general fluctuations in stock prices affected by market fluctuations. A securities that have beta $<1$ said a smaller risk than market risk. Instead of a security that has a beta value of $>1$ is said to have a larger systematic risk than market risk.

Return regarded as the best measure for prediction guidelines, assuming the market is efficient. Comparison between return and risk show investors, that the higher the risk the higher the expected return. To analyze the performance of the Treynor's model required data such as average return, beta stocks, and the risk free rate. The results of the calculation of the stock performance of the 10 groups of stocks Jakarta Islamic Index using Treynor's model can be seen in table 4 .

Table 4. Stock's Performance Using Treynor's Model

\begin{tabular}{cccccc}
\hline Emiten & $\mathbf{2 0 0 8}$ & $\mathbf{2 0 0 9}$ & $\mathbf{2 0 1 0}$ & $\mathbf{2 0 1 1}$ & $\mathbf{2 0 1 2}$ \\
\hline AALI & $-331,522$ & 2634,615 & 167,857 & 387,234 & $-221,053$ \\
ANTM & $-1125,773$ & 480,620 & 54,861 & 1350 & $-171,951$ \\
ASII & $-1248,571$ & 1296,296 & 249,324 & $-622,222$ & $-159,553$
\end{tabular}




\begin{tabular}{cccccc} 
CPIN & $-550,926$ & 3359,574 & 203,143 & $-502,500$ & $-417,544$ \\
INDF & $-809,804$ & 817,007 & 308,642 & $-478,571$ & 277,778 \\
KLBF & $-1103,704$ & -36400 & 730 & $-21,622$ & 303,738 \\
LSIP & $-464,740$ & 713,178 & 95,968 & $-1182,540$ & $-446,154$ \\
SMGR & $-396,970$ & 372,093 & 178,161 & $-203,797$ & 363,014 \\
TLKM & $-479,412$ & 670,175 & $-343,284$ & 925 & 306,061 \\
UNTR & $-243,558$ & 1627,941 & 366,292 & -200 & $-29,752$ \\
\hline
\end{tabular}

Source: Indonesia Stock Exchange

Table 4 shows that the Treynor index of the period 2008 to 2012 was in the range -1248.571 up to 3359.574 . If the value of Treynor index is positive and increased, the stock performance will getting better. Table 4 shows that there is a stock from 2008 until 2012 always show increased Treynor's performance index, namely: ASII, CPIN, INDF, KLBF, LSIP, SMGR, and TLKM. The period 2008 to 2012, shows that there are some stocks still have the negative Treynor index in each year. This indicates that the stock portfolios formed Jakarta Islamic Index, the Treynor performance is not all be positive. The data in Table 4 shows that there is a stock from 2008 until 2012, show a decrease in Treynor's performance index, namely: AALI, ANTM and UNTR.

Jensen method calculated the value of the investment return exceeds the expected return or the minimum rate of return. Return is the average return the previous period. To analyze the method of Jensen require data such as average return, beta stocks, and the risk free rate. The results of the calculation of the stock's performance of the tenth group of stocks Jakarta Islamic Index Jensen method in Table 5.

Table 5. Stock's Performance Using Jensen's Model

\begin{tabular}{crrrrr}
\hline Emiten & $\mathbf{2 0 0 8}$ & \multicolumn{1}{c}{$\mathbf{2 0 0 9}$} & \multicolumn{1}{c}{$\mathbf{2 0 1 0}$} & \multicolumn{1}{c}{$\mathbf{2 0 1 1}$} & \multicolumn{1}{c}{$\mathbf{2 0 1 2}$} \\
\hline AALI & 633,840 & 537,840 & 6,640 & $-100,690$ & $-107,940$ \\
ANTM & $-436,280$ & $-110,140$ & $-145,640$ & $-306,020$ & $-192,660$ \\
ASII & $-601,200$ & 591,540 & 138,120 & 286,280 & $-1094,960$ \\
CPIN & 135,080 & 1312,980 & 165 & 270,200 & 547,820 \\
INDF & $-136,480$ & 368,980 & 123,640 & $-91,220$ & 135,310 \\
KLBF & $-346,440$ & 1108,980 & 631,400 & 72,010 & $-257,590$ \\
LSIP & 365,480 & 189,860 & $-74,440$ & $-853,990$ & 66,190 \\
SMGR & 184,160 & $-250,140$ & 19,280 & 297,670 & 219,010 \\
TLKM & 133,680 & 59,380 & $-334,520$ & $-120,320$ & 160,420 \\
UNTR & 704,880 & 722,120 & 187,160 & 134,280 & $-112,230$ \\
\hline
\end{tabular}

Source: Indonesia Stock Exchange 
Table 5 shows that the index Jensen from the period 2008 to 2012 was in the range -1094.960 until 1108.980. If the value of Alpha Jensen highest and significant shows that this portfolio is the best of the existing portfolio. Alpha which has a positive value indicates a better performance than the market index; while a negative value indicates a lower performance than the market index. As in Table 5, there are stocks from 2008 to 2012 that always showed an increase Jensen index, namely: ANTM, CPIN, INDF, KLBF, LSIP, SMGR, and TLKM. However, from the results of Jensen index calculation, there are stocks that have a negative value. Some stocks which show a decrease in Jensen index is: AALI, ASII, and UNTR.

Table 6. Rating of Shariah Stock's Performance (year 2008 - 2010)

\begin{tabular}{cccccccccc}
\hline & \multicolumn{3}{c}{$\mathbf{2 0 0 8}$} & \multicolumn{4}{c}{$\mathbf{2 0 0 9}$} \\
No. & Sharpe & Treynor & Jensen & Sharpe & Treynor & Jensen & Sharpe & Treynor & Jensen \\
\hline 1. & UNTR & UNTR & UNTR & AALI & CPIN & CPIN & KLBF & UNTR & KLBF \\
2. & SMGR & AALI & AALI & UNTR & AALI & KLBF & UNTR & INDF & UNTR \\
3. & AALI & SMGR & LSIP & INDF & UNTR & UNTR & ASII & ASII & CPIN \\
4. & TLKM & LSIP & SMGR & ASII & ASII & ASII & INDF & CPIN & ASII \\
5. & LSIP & TLKM & CPIN & CPIN & INDF & AALI & SMGR & SMGR & INDF \\
\hline
\end{tabular}

Source: Indonesia Stock Exchange

Stock performance will be measured using three different methods, namely Methods Sharpe, Treynor, and Jensen. Measurement of performance shares for the three different methods require data such as stock returns, standard deviation, the market return and risk free rate. Tables 6 and 7 show the best performance ratings Islamic stock during the period 2008 to 2012.

Table 7. Rating of Shariah Stock's Performance (year 2011-2012)

\begin{tabular}{ccccccc}
\hline \multirow{2}{*}{ No. } & & $\mathbf{2 0 1 1}$ & & & $\mathbf{2 0 1 2}$ & \\
& Sharpe & Treynor & Jensen & Sharpe & Treynor & Jensen \\
\hline 1. & ASII & ANTM & SMGR & INDF & SMGR & CPIN \\
2. & LSIP & TLKM & ASII & CPIN & TLKM & SMGR \\
3. & SMGR & AALI & CPIN & SMGR & KLBF & TLKM \\
4. & CPIN & KLBF & UNTR & TLKM & INDF & INDF \\
5. & UNTR & SMGR & KLBF & LSIP & UNTR & LSIP \\
\hline
\end{tabular}

Source: Indonesia Stock Exchange

Given the formulation and performance measurement characteristics of each are different, then the value of the performance index obtained from the calculation of index numbers are different. Each of these methods has a basic stock performance relative numbers can't be compared directly with one another given 
measurement method is different. The results show a significant difference in the performance measurement method. Treynor method show consistency among the three measurements, as Treynor had a mean difference of the lowest rank of the methods Sharpe and Jensen (Sulistyorini, 2009). According to the ranking of stock's performance using the three measurement show that there are consistency of stock that have a best rank, i.e. AALI, ANTM, ASII, CPIN, INDF, KLBF, LSIP, and UNTR.

\section{Conclusion}

Judging from the results of the return of each stock that the whole of the period of the study in 2008-2012 AALI (Astra Agro Lestari Tbk), ANTM (Antam (Persero) Tbk), CPIN (Charoen Pokphand Indonesia Tbk), INDF (Indofood Sukses Makmur Tbk), KLBF (Kalbe Farma Tbk), LSIP (PP London Sumatra, PT), SMGR (Semen Gresik (Persero) Tbk), and TLKM (Telecommunications Indonesia, Tbk) have consistency for the highest return. These results can be a reference for investors to facilitate stock is chosen to invest, investors can choose companies in major sectors, meaning the company in the field of basic human needs, such as food ingredients, food, building materials (infrastructure) and others which will certainly continue to increase the performance of the company because every year definitely increase the demand for these needs.

The results obtained from the calculation of the Islamic stock performance with the method of Risk Adjusted Performance shows that the Islamic stocks have performed well, because it tends to increase each year. Based on the rating sharia stock performance calculation by using method Sharpe, Treynor and Jensen show that there is the consistency of shares whose have the best ratings in each year. These shares are AALI (Astra Agro Lestari Tbk), ANTM (Antam (Persero) Tbk), ASII (Astra International, Tbk), CPIN (Charoen Pokphand Indonesia Tbk), INDF (Indofood Sukses Makmur Tbk), KLBF (Kalbe Farma Tbk), LSIP (PP London Sumatra, PT), and UNTR (United Tractors Tbk). It could also be a reference to strengthening investor to invest in the stock. In addition to this performance analysis, can also use technical and fundamental analysis in order to know the ins and outs of the company's performance from year to year and his track record does include companies that are healthy or not.

\section{References}

Al Arif, M.N.R. 2012. Islamic Financial Institutions. Bandung: Pustaka Setia. Chapra, M.U. 1996. Monetary Policy in an Islamic Economy in Money and Banking in Islam. Jeddah: International Centre for Research in Islamic Economics. 
Darmawi, H. 2006. Financial Market and Other Financial Institutions. Jakarta: PT. Bumi Aksara.

Fakhruddin, M.H. 2008. The Dictionary of Capital Market From A to Z. Jakarta: PT. Elex Media Komputindo.

Hadi, N. 2013. The Capital Market: Theoretical and Practice as Financial Market Instruments. Yogyakarta: Graha Ilmu.

Hamid, A. 2009. Islamic Capital Market. Jakarta: Lembaga Penelitian UIN Jakarta.

Huda, N. \& M.E. Nasution. 2009. Current Issues on Islamic Financial Institutions. Jakarta: Kencana.

Huda, N. \& M. Heykal. 2010. Islamic Financial Institutions: A Theoretical and Practice Perception. Jakarta: Kencana.

Hulwati. 2009. Islamic Economics: Theory and Practice on Islamic Bonds Trading in Islamic Capital Market Indonesia and Malaysia. Jakarta: Ciputat Press Group.

Manan, A. 2009. The Legal Aspect of Investment on Indonesian Islamic Capital Market. Jakarta: Kencana.

Muhammad. 2007. The Legal Aspect on Muamalah. Yogyakarta: Graha Ilmu.

Nafik, H.R. \& Muhammad. 2009. Stock Exchange and Islamic Investment. Jakarta: Serambi.

Noor, H.F. 2009. Investment: The Financial Management on Business and The Economy Development of Community. Jakarta: PT Index.

Samsul, M. 2006. Capital Market and Portfolio Management. Jakarta: Erlangga.

Sulistyorini, A. 2009. The Stock Portfolio Performance Analysis Using Sharpe, Treynor and Jensen: Study on LQ 45 Stock at Indonesia Stock Exchange. (Thesis Unpublished). Semarang: University of Diponegoro.

Sutedi, A. 2011. Islamic Capital Market: The Financial Investment Instrument Based on Islamic Principle. Jakarta: Sinar Grafika.

Zubir, Z. 2011. Portfolio Management: The Application in Stock Investment. Jakarta: Salemba Empat. 